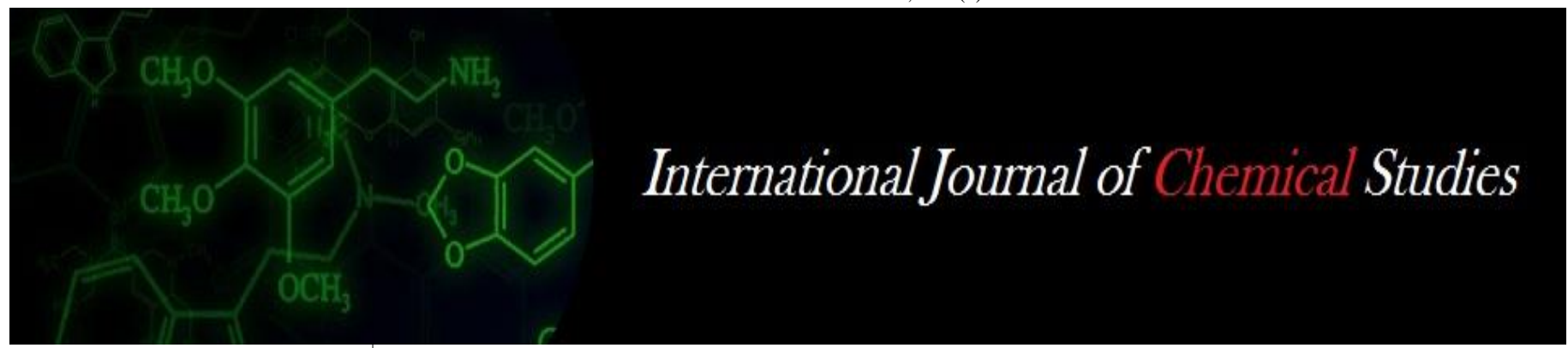

P-ISSN: 2349-8528

E-ISSN: 2321-4902

www.chemijournal.com

IJCS 2020; SP-8(5): 249-254

(C) 2020 IJCS

Received: 02-07-2020

Accepted: 09-08-2020

\section{Marviya PB}

Department of Agricultural

Statistics, Sardarkrushinagar

Dantiwada Agricultural

University, Sardarkrushinagar,

Gujarat, India

\section{Jadeja RM}

Department of Agricultural

Economics, Sardarkrushinagar

Dantiwada Agricultural

University, Sardarkrushinagar,

Gujarat, India

\section{Shitap MS}

Department of Agricultural Statistics, Junagadh Agricultural University, Junagadh, Gujarat, India

\section{Corresponding Author:}

\section{Marviya PB}

Department of Agricultural

Statistics, Sardarkrushinagar

Dantiwada Agricultural

University, Sardarkrushinagar,

Gujarat, India

\section{A statistical investigation on relationship between weather parameters and chickpea yield in Jamnagar district of Gujarat state}

\author{
Marviya PB, Jadeja RM and Shitap MS
}

DOI: https://doi.org/10.22271/chemi.2020.v8.i5e.10618

\begin{abstract}
An attempt has been made to quantify the effect of climate change on chickpea production and relationship between weather parameters and yield of chickpea crop in Jamnagar district of Gujarat state. Crop production and productivity depend on climate in general and weather in particular. The productivity of the crop depends on soil characteristics and weather conditions during season. The present study of forecasting of gram crop yield for Jamnagar district based on weekly average data of weather parameters viz. minimum temperature $\left(\mathrm{X}_{1}\right)$, maximum temperature $\left(\mathrm{X}_{2}\right)$, morning relative humidity $\left(\mathrm{X}_{3}\right)$, afternoon relative humidity $\left(\mathrm{X}_{4}\right)$, sunshine hours $\left(\mathrm{X}_{5}\right)$ and total annual rainfall of past year $\left(\mathrm{X}_{6}\right)$ were analyzed for the crop weather relationship to develop regression model. The time trend (T) was also included as explanatory variable. The data pertaining for the period of 30 years weather and crop yield records of Jamnagar district were collected. The approach used for forecasting yield was original weather variables and week wise approach. The time trend was include as an explanatory variable. For this district, the model of 14 weeks period (week wise approach) was selected. Result revealed that the model of 14 weeks crop period could be suggested as a pre-harvest forecast model. The variation explained by this model was $86.17 \%\left(\mathrm{R}^{2}\right)$ and simulated forecast error was less than $7 \%$. The model for Jamnagar district can be used for providing pre-harvest forecast two weeks before expected harvest.
\end{abstract}

Keywords: Weather parameters, chickpea, regression, statistical model, forecasting

\section{Introduction}

Agriculture is the major economic and social activity in the globe. It is understood that agriculture is highly sensitive to climatic variability and likely to be affected most too predicted climate change. India is predominantly an agriculture dependent nation and the south west monsoon plays an important role in its economy. There are many weather variables which affect crop growth and development in different ways and at different times during the growth cycle of the crop. Weather has long been recognized as major control over growth and yield of crops.

During 2013-14, chickpea production exceeded 9.5 million tones attaining highest peak in production in the history of its cultivation in India. Unfortunately, the production is estimated to witness a setback due to hostile weather conditions and predicted to tally at 7.17 million tones. However, this is a temporary phase and is likely to be compensated by a better production figures in the coming years.

In India, Madhya Pradesh, Rajasthan, Maharashtra, Uttar Pradesh, Andhra Pradesh, Karnataka, Chhattisgarh, Bihar and Jharkhand are major chickpea producing states contributing more than 95\% to the total chickpea production. Madhya Pradesh is the single largest producer in the country accounting for over $40 \%$ of total production while Rajasthan, Maharashtra, Uttar Pradesh and Andhra Pradesh contribute about 14\%, 10\%, 9\% and 7\%, respectively. In Gujarat, gram occupied an area of 2.47 lack hectares with a production of 3.09 lack tone with an average productivity of $1251 \mathrm{~kg} / \mathrm{ha}$ (Dixit, 2015) ${ }^{[1]}$. Jamnagar district belongs to South Saurashtra Agro-climatic Zone with an average productivity of chickpea is $1246 \mathrm{~kg} / \mathrm{ha}$.

The weather variables like rainfall, maximum and minimum temperature, relative humidity and sunshine hours affect growth and development in different ways and at different times during the growth cycle of the crop. The relationship between crop yields and weather parameters can be identified with the help of multiple regression models (Agrawal et al., 2001) [2]. 
The present study was undertaken to investigate the feasibility of estimating chickpea yields by regression analysis of few representative districts of Gujarat state majoring in area and production from the weather parameters and technological advances. The main objectives of the investigation are,

1. To study the effect of weather parameters on productivity of chickpea for Jamnagar district in Gujarat state.

2. To develop suitable statistical models for forecasting chickpea productivity of Jamnagar district in Gujarat state.

\section{Materials and Methods}

With a view to development of forecasting model of chickpea for Jamnagar district of Gujarat by using combined effect of weather parameters. Considering the specific objective of the study, chickpea yield data of Jamnagar district for the years 1981 to 2010 were obtained from the Department of Economics, J.A.U., Junagadh. The complete meteorological data of Jamnagar (Lat: $22^{\circ}-27^{`} \mathrm{~N}$, Long: $70^{\circ}-07^{\prime} \mathrm{E}$ ) were collected from Agromet observatory of Jamnagar Research Station of JAU for the corresponding period.

\section{Weather Parameters}

The corresponding data on weather parameters were collected from the weather stations or meteorological observatory situated in Jamnagar. For this study weekly average weather data were collected for the growing season of chickpea. The following variables were considered.

Y: Average chickpea yield of the district in $\mathrm{kg} / \mathrm{ha}$.

T: Time trend, year number included to correct for upward or downward trend in yield.

$\mathrm{X}_{1}$ : Minimum temperature $\left({ }^{0} \mathrm{C}\right)$

$\mathrm{X}_{2}$ : Maximum temperature $\left({ }^{0} \mathrm{C}\right)$

$\mathrm{X}_{3}$ : Morning relative humidity $(\%)$

$\mathrm{X}_{4}$ : After noon relative humidity $(\%)$

$\mathrm{X}_{5}$ : Sunshine hours (hrs)

$\mathrm{X}_{6}$ : Total rainfall of past year $(\mathrm{mm})$

Statistical computer software Microstat was used for the analysis of the data with the probability level 0.05 and 0.1 to remove the variables. Using original weather variables, week wise approach were used.

With a view to assess the accuracy and capability of earlier forecasts at an interval of weeks, four models were fitted, considering up to $12,13,14$ and 15 weeks after sowing during the crop period. The details of variables included in model up to 18 weeks crop period are given in [Table 2]. The time trend variable was included in this analysis as an explanatory variable.

The details on crop season of chickpea, meteorological standard weeks and physiological stages of chickpea crop are given in [Table 1].

Table 1: Various physiological stages and meteorological standard week of chickpea crop

\begin{tabular}{|c|c|c|c|c|}
\hline Sr. No & Stages & Crop duration ( days ) & Meteo. Week & Meteo. Period \\
\hline 1 & Establishment & $7-10$ & $42-43$ & 15th Oct. to 28th Oct. \\
\hline 2 & Vegetative & $11-40$ & $44-48$ & 29th Nov. to 2nd Dec. \\
\hline 3 & Flowering & $40-50$ & $49-51$ & 3rd Dec. to 23rd Dec. \\
\hline 4 & Maturity & $95-120$ & $52-05$ & 24th Dec. to 28th Feb. \\
\hline
\end{tabular}

Table 2: Variables included in the model week wise approach up to 18 weeks crop period

\begin{tabular}{|c|c|c|c|c|c|c|c|}
\hline \multirow{3}{*}{ Meteo. Std. week No. (MSW) } & \multirow{3}{*}{ Crop Week No. } & \multicolumn{2}{|c|}{ Temperature } & \multicolumn{2}{|c|}{ Relative humidity } & \multirow{2}{*}{$\begin{array}{c}\text { Sunshine } \\
\text { hours }\end{array}$} & \multirow{2}{*}{ Rainfall } \\
\hline & & Max. & Min. & M & $\mathbf{E}$ & & \\
\hline & & $\mathbf{X}_{1 \mathbf{j}}$ & $\mathbf{X}_{\mathbf{2 j}}$ & $\mathbf{X}_{\mathbf{3 j}}$ & $\mathbf{X}_{4 \mathbf{j}}$ & $\mathbf{X}_{\mathbf{5 j}}$ & $\mathbf{X}_{6}$ \\
\hline 42 & 01 & $\mathrm{X}_{101}$ & $\mathrm{X}_{201}$ & $\mathrm{X}_{301}$ & $\mathrm{X}_{401}$ & $\mathrm{X}_{501}$ & \multirow{18}{*}{$\mathrm{X}_{6}$} \\
\hline 43 & 02 & $\mathrm{X}_{102}$ & $\mathrm{X}_{202}$ & $\mathrm{X}_{302}$ & $\mathrm{X}_{402}$ & $\mathrm{X}_{502}$ & \\
\hline 44 & 03 & $\mathrm{X}_{103}$ & $\mathrm{X}_{203}$ & $\mathrm{X}_{303}$ & $\mathrm{X}_{403}$ & $\mathrm{X}_{503}$ & \\
\hline 45 & 04 & $\mathrm{X}_{104}$ & $\mathrm{X}_{204}$ & $\mathrm{X}_{304}$ & $\mathrm{X}_{404}$ & $\mathrm{X}_{504}$ & \\
\hline 46 & 05 & $\mathrm{X}_{105}$ & $\mathrm{X}_{205}$ & $\mathrm{X}_{305}$ & $\mathrm{X}_{405}$ & $\mathrm{X}_{505}$ & \\
\hline 47 & 06 & $\mathrm{X}_{106}$ & $\mathrm{X}_{206}$ & $X_{306}$ & $\mathrm{X}_{406}$ & $X_{506}$ & \\
\hline 48 & 07 & $\mathrm{X}_{107}$ & $\mathrm{X}_{207}$ & $\mathrm{X}_{307}$ & $\mathrm{X}_{407}$ & $\mathrm{X}_{507}$ & \\
\hline 49 & 08 & $\mathrm{X}_{108}$ & $\mathrm{X}_{208}$ & $\mathrm{X}_{308}$ & $\mathrm{X}_{408}$ & $\mathrm{X}_{508}$ & \\
\hline 50 & 09 & $\mathrm{X}_{109}$ & $X_{209}$ & $X_{309}$ & $X_{409}$ & $\mathrm{X}_{509}$ & \\
\hline 51 & 10 & $X_{110}$ & $\mathrm{X}_{210}$ & $\mathrm{X}_{310}$ & $\mathrm{X}_{410}$ & $\mathrm{X}_{510}$ & \\
\hline 52 & 11 & $X_{111}$ & $\mathrm{X}_{211}$ & $X_{311}$ & $\mathrm{X}_{411}$ & $\mathrm{X}_{511}$ & \\
\hline 1 & 12 & $\mathrm{X}_{112}$ & $\mathrm{X}_{212}$ & $\mathrm{X}_{312}$ & $\mathrm{X}_{412}$ & $\mathrm{X} 5_{12}$ & \\
\hline 2 & 13 & $\mathrm{X}_{113}$ & $\mathrm{X}_{213}$ & $\mathrm{X}_{313}$ & $\mathrm{X}_{413}$ & $\mathrm{X}_{513}$ & \\
\hline 3 & 14 & $\mathrm{X}_{114}$ & $\mathrm{X}_{214}$ & $\mathrm{X}_{314}$ & $\mathrm{X}_{414}$ & $\mathrm{X}_{514}$ & \\
\hline 4 & 15 & $\mathrm{X}_{115}$ & $\mathrm{X}_{215}$ & $\mathrm{X}_{315}$ & $\mathrm{X}_{415}$ & $\mathrm{X}_{515}$ & \\
\hline 5 & 16 & $\mathrm{X}_{116}$ & $\mathrm{X}_{216}$ & $\mathrm{X}_{316}$ & $\mathrm{X}_{416}$ & $\mathrm{X}_{516}$ & \\
\hline 6 & 17 & $\mathrm{X}_{117}$ & $\mathrm{X}_{217}$ & $\mathrm{X}_{317}$ & $\mathrm{X}_{417}$ & $\mathrm{X}_{517}$ & \\
\hline 7 & 18 & $\mathrm{X}_{118}$ & $\mathrm{X}_{218}$ & $\mathrm{X}_{318}$ & $\mathrm{X}_{418}$ & $\mathrm{X}_{518}$ & \\
\hline \multicolumn{4}{|c|}{$\mathrm{T}=$ Time trend } & \multicolumn{2}{|c|}{$Y=$ Yield } & & \\
\hline
\end{tabular}

The mathematical expression of this approach, (Fisher, 1924) ${ }^{[3]}$

Where,

$\mathrm{Y}=$ Average chickpea yield of district in $\mathrm{kg} / \mathrm{ha}$

$\mathrm{A}_{0}=$ Constant

$\mathrm{X}_{\mathrm{ij}}=$ Observed value of $\mathrm{i}^{\text {th }}$ weather variable in $\mathrm{j}^{\text {th }}$ week $\mathrm{i}=$

$1,2, \ldots$

$\mathrm{p}=6$ and $\mathrm{j}=1,2, \ldots, \mathrm{w}=12,13,14,15$
$\mathrm{R}=$ Total rainfall of past season of the district in $\mathrm{mm}$.

$\mathrm{T}=$ Year number included to correct for the long term upward or downward trend in yield $(\mathrm{T}=1,2 \ldots \mathrm{t}=30)$

$\mathrm{a}_{\mathrm{ij}}, \mathrm{b}$ and $\mathrm{c}$ are partial regression coefficients associated with each $\mathrm{X}_{\mathrm{ij}}$, rainfall and time trend $(\mathrm{T})$ respectively. 


\section{Selection of Variables}

For selecting the best regression equation with significant independent variables among number of independent variables the stepwise regression procedure was adopted (Draper and Smith, 1966) ${ }^{[4]}$. The best regression equation for predictive purpose should be such as would include as many independent variables as possible, but at the same time, reject all those variables which do not contribute significantly to the prediction model. There is no unique statistical procedure to compromise between these two extremes, but stepwise regression analysis procedure which is generally applied under such circumstances and considered as the best selection procedure.

\section{Simulated Forecast Model}

Using these fitted prediction equations, simulated forecasts were obtained for subsequent years, which were not included in the model. The per cent deviations of these forecasts from the reported yields were worked out to assess the suitability of these equations as pre-harvest forecast models. Finally, the model which provided the early forecast and accounted more than 80 per cent of the total variation and which did not deviate much more $(<20 \%)$ from the observed yields of the district, were considered as pre-harvest forecasts models.

\section{Results and discussion}

To determine the effect of week wise weather variables on chickpea yield, the variables which appeared in the equation and had significant partial regression coefficient were considered to have influence on chickpea production. The results presented in two parts for each crop period for the model. First part deals with fitted regression equations and second part deals with their corresponding simulated forecasts for subsequent years not including for obtaining the regressions.

The result related to 12 week period model, indicated that time trend, minimum temperature of $6^{\text {th }} \& 11^{\text {th }}$ week $\left(\mathrm{X}_{106}\right.$, $\left.\mathrm{X}_{111}\right)$, maximum temperature of $6^{\text {th }}$ week $\left(\mathrm{X}_{206}\right)$ and morning relative humidity of 11 th week $\left(\mathrm{X}_{311}\right)$ significantly and positively influenced the chickpea crop yield. The influence of maximum temperature of $1^{\text {st }}$ week, 4 th week $\left(X_{201}, X_{204}\right)$ and afternoon relative humidity of 9 th week $\left(X_{409}\right)$ were negative. The weeks correspond to vegetative stage of chickpea crop. The variation explained by these variables in fitted models of 12 week period data ranged from 70.49 to $77.59 \%$ [Table 3]. The simulated forecasts of subsequent years not included in obtaining regression equations, showed 6.68 to 30.40 per cent deviation from the actual district average chickpea yield [Table 4].

Table 3: Regression equations for 12 - week crop period

\begin{tabular}{|c|c|c|c|c|}
\hline \multirow{2}{*}{ Variables In model } & \multicolumn{4}{|c|}{ Models for different years } \\
\cline { 2 - 5 } & Model-I (25 year) & Model-II (26 year) & Model-III (27 year) & Model-IV (28 year) \\
\hline Constant & 3204.81 & 3051.03 & 3068.12 & 2983.60 \\
\hline $\mathrm{T}$ & $21.11^{* *}$ & $21.40^{* *}$ & $21.48^{* *}$ & $23.35^{* *}$ \\
\hline $\mathrm{X}_{106}$ & $18.97^{* *}$ & $20.98^{* *}$ & $21.80^{* *}$ & $28.94^{* *}$ \\
\hline $\mathrm{X}_{111}$ & $66.30^{* *}$ & $75.76^{* *}$ & $74.87^{* *}$ & $81.17^{* *}$ \\
\hline $\mathrm{X}_{201}$ & $-73.37^{* *}$ & $-73.22^{* *}$ & $-72.90^{* *}$ & $-67.11^{* *}$ \\
\hline $\mathrm{X}_{204}$ & $-63.82^{* *}$ & $-59.60^{* *}$ & $-60.08^{* *}$ & $-50.20^{* *}$ \\
\hline $\mathrm{X}_{206}$ & $28.28^{* *}$ & $23.19^{* *}$ & $22.96^{* *}$ & $1.81^{* *}$ \\
\hline $\mathrm{X}_{311}$ & $1.82^{* *}$ & $2.66^{* *}$ & $2.48^{* *}$ & $2.66^{* *}$ \\
\hline $\mathrm{X}_{409}$ & $-2.02^{*}$ & $-2.43^{*}$ & $-2.36^{*}$ & $-1.98^{*}$ \\
\hline $\mathrm{S} . \mathrm{E}$. & 190.49 & 186.90 & 181.67 & 186.27 \\
\hline $\mathrm{R} 2(\%)$ & 70.49 & 75.20 & 76.82 & 77.59 \\
\hline
\end{tabular}

*Significant at $5 \%$ level. ** Significant at $1 \%$ level.

Table 4: Simulated forecast values for 12 - week crop period

\begin{tabular}{|c|c|c|c|c|c|}
\hline \multirow{2}{*}{ Year } & \multirow{2}{*}{ Observed yield (kg/ha) } & \multicolumn{4}{|c|}{ Predicted values ( kg/ha) } \\
\cline { 3 - 6 } & & Model-I 25 years & Model-II 26 years & Model-III 27 years & Model-IV 28 years \\
\hline $2006-07$ & 1168 & $1246(6.68)$ & -- & -- & -- \\
\hline $2007-08$ & 1392 & $1146(17.68)$ & $1185(14.88)$ & -- & -- \\
\hline $2008-09$ & 1327 & $1027(22.60)$ & $1078(18.78)$ & $1076(18.91)$ & -- \\
\hline $2009-10$ & 1474 & $1154(21.70)$ & $1204(18.31)$ & $1198(18.72)$ & $1275(10.66)$ \\
\hline $2010-11$ & 1539 & $1071(30.40)$ & $1134(26.31)$ & $1136(26.18)$ & $1316(14.48)$ \\
\hline
\end{tabular}

Figures in ( ) are percent deviation from observed yield.

The result presented in case of 13 week period model, revealed that variables such as time trend, minimum temperature of $6^{\text {th }}$ week $\& 11^{\text {th }}$ week $\left(\mathrm{X}_{106}, \mathrm{X}_{111}\right)$, morning relative humidity of $1^{\text {st }} \& 11^{\text {th }}$ week $\left(\mathrm{X}_{301}, \mathrm{X}_{311}\right)$ and morning relative humidity of $13^{\text {th }}$ week $\left(\mathrm{X}_{413}\right)$ were positive and significant effected on crop yield. The maximum temperature of $1^{\text {st }}, 4^{\text {th }} \& 8^{\text {th }}$ week $\left(\mathrm{X}_{201}, \mathrm{X}_{204}, \mathrm{X}_{208}\right)$ morning relative humidity of $7^{\text {th }}$ week $\left(\mathrm{X}_{307}\right)$ and afternoon relative humidity of $13^{\text {th }}$ week $\left(X_{409}\right)$ showed negative and significantly predicted the yield. The weeks correspond to flowering stage. The coefficient of determination $\left(\mathrm{R}^{2}\right)$ varied from 80.12 to $84.86 \%$ [Table 5]. The simulated forecasts showed deviation from observed yield ranged from 11.32 to 27.35 per cent [Table 6]. 
Table 5: Regression equations for 13-week crop period

\begin{tabular}{|c|c|c|c|c|}
\hline \multirow{2}{*}{ Variables in model } & \multicolumn{4}{|c|}{ Models for different years } \\
\cline { 2 - 5 } & Model-I (25 year) & Model-II (26 year) & Model-III (27 year) & Model-IV (28 year) \\
\hline Constant & 3818.00 & 3766.76 & 3774.57 & 3673.21 \\
\hline $\mathrm{T}$ & $22.28^{* *}$ & $21.56^{* *}$ & $21.60^{* *}$ & $22.62^{* *}$ \\
\hline $\mathrm{X}_{106}$ & $37.70^{* *}$ & $35.20^{* *}$ & $35.56^{* *}$ & $36.86^{* *}$ \\
\hline $\mathrm{X}_{111}$ & $71.31^{* *}$ & $63.87^{* *}$ & $63.50^{* *}$ & $73.36^{* *}$ \\
\hline $\mathrm{X}_{201}$ & $-57.36^{* *}$ & $-54.50^{* *}$ & $-54.41^{* *}$ & $-57.05^{* *}$ \\
\hline $\mathrm{X}_{204}$ & $-30.22^{* *}$ & $-31.19^{* *}$ & $-31.47^{* *}$ & $-30.45^{* *}$ \\
\hline $\mathrm{X}_{208}$ & $-57.36^{* *}$ & $-54.28^{* *}$ & $-54.25^{* *}$ & $-49.11^{* *}$ \\
\hline $\mathrm{X}_{301}$ & $3.52^{* *}$ & $3.54^{* *}$ & $3.54^{* *}$ & $1.62^{* *}$ \\
\hline $\mathrm{X}_{307}$ & $-9.90^{*}$ & $-10.21^{*}$ & $-10.21^{*}$ & $-11.49^{*}$ \\
\hline $\mathrm{X}_{311}$ & $5.54^{* *}$ & $5.79^{* *}$ & $5.70^{* *}$ & $7.22^{* *}$ \\
\hline $\mathrm{X}_{409}$ & $-0.09^{*}$ & $-0.89^{*}$ & $-0.85^{*}$ & $0.17^{*}$ \\
\hline $\mathrm{X}_{413}$ & $0.40^{* *}$ & $0.80^{* *}$ & $0.78^{* *}$ & $0.20^{* *}$ \\
\hline $\mathrm{S}_{\mathrm{n} . \mathrm{y}}$ & 173.46 & 167.81 & 162.13 & 166.86 \\
\hline $\mathrm{R}^{2}(\%)$ & 80.12 & 83.54 & 84.62 & 84.86 \\
\hline
\end{tabular}

*Significant at 5\% level. ** Significant at $1 \%$ level.

Table 6: Simulated forecast values for 13 - week crop period

\begin{tabular}{|c|c|c|c|c|c|}
\hline \multirow{2}{*}{ Year } & \multirow{2}{*}{ Observed yield (kg/ha) } & \multicolumn{4}{|c|}{ Predicted values ( kg/ha) } \\
\cline { 2 - 6 } & & Model-I 25 years & Model-II 26 years & Model-III 27 years & Model-IV 28 years \\
\hline $2006-07$ & 1168 & $1478(26.54)$ & -- & -- & -- \\
\hline $2007-08$ & 1392 & $1199(13.87)$ & $1176(15.51)$ & -- & -- \\
\hline $2008-09$ & 1327 & $1138(14.24)$ & $1118(15.74)$ & $1117(15.83)$ & -- \\
\hline $2009-10$ & 1474 & $1307(11.32)$ & $1272(13.70)$ & $1271(13.77)$ & $1294(12.21)$ \\
\hline $2010-11$ & 1539 & $1118(27.35)$ & $1302(15.39)$ & $1328(13.71)$ & $1346(12.54)$ \\
\hline
\end{tabular}

Figures in ( ) are percent deviation from observed yield.

In case of 14 week crop period, result revealed that there is a positive and significant effect of time trend $(\mathrm{T})$ and minimum temperature of $6^{\text {th }}, 11^{\text {th }} \& 14^{\text {th }}$ week $\left(\mathrm{X}_{106}, \mathrm{X}_{111}, \mathrm{X}_{114}\right)$. The negative and significant effect influence on chickpea crop is observed in case of minimum temperature of $12^{\text {th }}$ week $\left(\mathrm{X}^{112}\right)$, maximum temperature of $1^{\text {st }}, 4^{\text {th }} \& 8^{\text {th }}$ week $\left(\mathrm{X}_{201}, \mathrm{X}_{204}\right.$ and $\left.\mathrm{X}_{208}\right)$ and afternoon relative humidity of 9 th week $\left(\mathrm{X}_{409}\right)$ in all four models. The weeks correspond to sowing and vegetative stages of chickpea crop. The coefficient of determination $\left(\mathrm{R}^{2}\right)$ varied from 80.10 to $86.17 \%$ and the predicted values [Table 7] showed 6.93 to 24.49 per cent deviation [Table 8] from recorded yield of Jamnagar district.
The analyzed result related to the 15 week crop period, represented in the [Table 9] revealed that there is a positive and significant effect of time trend $(\mathrm{T})$ minimum temperature of $6^{\text {th }}, 11^{\text {th }} \& 15^{\text {th }}$ week $\left(\mathrm{X}_{106}, \mathrm{X}_{111} \& \mathrm{X}_{115}\right)$. The negative and significant effect on chickpea crop yield (Y) is observed in case of maximum temperature of $1^{\text {st }}, 4^{\text {th }}, 8^{\text {th }}, 11^{\text {th }} \& 12^{\text {th }}$ week and morning relative humidity of 15 th week $\left(\mathrm{X}_{315}\right)$ corresponding to the vegetative stage of the chickpea crop. The coefficient of determination $\left(\mathrm{R}^{2}\right)$ varied from 81.61 to $85.75 \%$ and the predicted values [Table 9] showed 3.24 to 20.28 per cent [Table 10] deviations from recorded yield of Jamnagar district.

Table 7: Regression equations for 14 - week crop period

\begin{tabular}{|c|c|c|c|c|}
\hline \multirow{2}{*}{ Variables in model } & \multicolumn{4}{|c|}{ Models for different years } \\
\cline { 2 - 5 } & Model-I (25 year) & Model-II (26 year) & Model-III (27 year) & Model-IV (28 year) \\
\hline Constant & 4199.75 & 4566.82 & 4230.91 & 4012.87 \\
\hline $\mathrm{T}$ & 20.18 & 20.15 & 20.62 & 20.93 \\
\hline $\mathrm{X}_{106}$ & $34.12^{* *}$ & $38.66^{* *}$ & $37.75^{* *}$ & $37.08^{* *}$ \\
\hline $\mathrm{X}_{111}$ & $87.37^{* *}$ & $86.08^{* *}$ & $86.17^{* *}$ & $88.12^{* *}$ \\
\hline $\mathrm{X}_{112}$ & $-40.78^{* *}$ & $-43.87^{* *}$ & $-39.43^{* *}$ & $-40.14^{* *}$ \\
\hline $\mathrm{X}_{114}$ & $39.66^{* *}$ & $42.89^{* *}$ & $37.53^{* *}$ & $48.97^{* *}$ \\
\hline $\mathrm{X}_{201}$ & $-57.75^{* *}$ & $-56.32^{* *}$ & $-57.10^{* *}$ & $-55.28^{* *}$ \\
\hline $\mathrm{X}_{204}$ & $-26.40^{* *}$ & $-32.71^{* *}$ & $-27.73^{* *}$ & $-26.94^{* *}$ \\
\hline $\mathrm{X}_{208}$ & $-74.23^{* *}$ & $-82.09^{* *}$ & $-75.19^{* *}$ & $-74.93^{* *}$ \\
\hline $\mathrm{X}_{311}$ & $-0.59^{*}$ & $-0.39^{*}$ & $-0.95^{*}$ & $-1.09^{*}$ \\
\hline $\mathrm{X}_{409}$ & $-1.37^{*}$ & $-3.03^{*}$ & $-1.26^{*}$ & $-0.89^{*}$ \\
\hline $\mathrm{S}_{\mathrm{n} . \mathrm{E} .}$ & 167.24 & 159.52 & 157.19 & 154.68 \\
\hline $\mathrm{R}^{2}(\%)$ & 80.10 & 84.06 & 84.58 & 86.17 \\
\hline
\end{tabular}

*Significant at 5\% level. ** Significant at $1 \%$ level.

Table 8: Simulated forecast values for 14 - week crop period

\begin{tabular}{|c|c|c|c|c|c|}
\hline \multirow{2}{*}{ Year } & \multirow{2}{*}{ Observed yield (kg/ha) } & \multicolumn{4}{|c|}{ Predicted values ( kg/ha) } \\
\cline { 3 - 6 } & & Model-I 25 years & Model-II 26 years & Model-III 27 years & Model-IV 28 years \\
\hline $2006-07$ & 1168 & $1343(14.98)$ & -- & -- & -- \\
\hline $2007-08$ & 1392 & $1217(12.57)$ & $1231(11.56)$ & -- & -- \\
\hline $2008-09$ & 1327 & $1215(8.44)$ & $1235(6.93)$ & $1225(7.68)$ & -- \\
\hline
\end{tabular}




\begin{tabular}{|c|c|c|c|c|c|}
\hline $2009-10$ & 1474 & $1119(24.08)$ & $1113(24.49)$ & $1121(23.94)$ & $1134(23.06)$ \\
\hline $2010-11$ & 1539 & $1391(9.61)$ & $1407(8.57)$ & $1409(8.44)$ & $1413(8.18)$ \\
\hline
\end{tabular}

Figures in ( ) are percent deviation from observed yield.

Table 9: Regression equations for 15 - week crop period

\begin{tabular}{|c|c|c|c|c|}
\hline \multirow{2}{*}{ Variables in model } & \multicolumn{4}{|c|}{ Models for different years } \\
\cline { 2 - 5 } & Model-I (25 year) & Model-II (26 year) & Model-III (27 year) & Model-IV (28 year) \\
\hline Constant & 6185.35 & 6174.84 & 6177.43 & 5519.35 \\
\hline $\mathrm{T}$ & $28.82^{* *}$ & $29.23^{* *}$ & $29.08^{* *}$ & $29.17^{* *}$ \\
\hline $\mathrm{X}_{106}$ & $23.28^{* *}$ & $25.92^{* *}$ & $28.04^{* *}$ & $19.71^{* *}$ \\
\hline $\mathrm{X}_{111}$ & $47.64^{* *}$ & $50.41^{* *}$ & $47.47^{* *}$ & $56.58^{* *}$ \\
\hline $\mathrm{X}_{115}$ & $35.18^{* *}$ & $33.00^{* *}$ & $32.80^{* *}$ & $40.88^{* *}$ \\
\hline $\mathrm{X}_{201}$ & $-69.88^{* *}$ & $-69.11^{* *}$ & $-69.46^{* *}$ & $-63.15^{* *}$ \\
\hline $\mathrm{X}_{204}$ & $-40.21^{* *}$ & $-40.20^{* *}$ & $-42.15^{* *}$ & $-31.77^{* *}$ \\
\hline $\mathrm{X}_{208}$ & $-70.65^{* *}$ & $-72.35^{* *}$ & $-71.88^{* *}$ & $-67.49^{* *}$ \\
\hline $\mathrm{X}_{211}$ & $-14.04^{*}$ & $-15.31^{*}$ & $-13.67^{*}$ & $-22.43^{*}$ \\
\hline $\mathrm{X}_{212}$ & $-5.96^{*}$ & $-5.35^{*}$ & $-4.39^{*}$ & $-5.77^{*}$ \\
\hline $\mathrm{X}_{315}$ & $-10.00^{*}$ & $-9.95^{*}$ & $-10.08^{*}$ & $-7.34^{*}$ \\
\hline $\mathrm{S} . \mathrm{E}$. & 160.76 & 155.66 & 151.30 & 157.02 \\
\hline $\mathrm{R}^{2}(\%)$ & 81.61 & 84.82 & 85.17 & 85.75 \\
\hline
\end{tabular}

*Significant at $5 \%$ level. ** Significant at $1 \%$ level.

Table 10: Simulated forecast values for 15 - week crop period of Jamnagar district

\begin{tabular}{|c|c|c|c|c|c|}
\hline \multirow{2}{*}{ Year } & \multirow{2}{*}{ Observed yield (kg/ha) } & \multicolumn{4}{|c|}{ Predicted values ( kg/ha) } \\
\cline { 3 - 6 } & & Model-I 25 years & Model-II 26 years & Model-III 27 years & Model-IV 28 years \\
\hline $2006-07$ & 1168 & $1335(14.29)$ & -- & -- & -- \\
\hline $2007-08$ & 1392 & $1218(12.5)$ & $1232(11.49)$ & -- & -- \\
\hline $2008-09$ & 1327 & $1104(16.80)$ & $1111(16.27)$ & $1098(17.25)$ & -- \\
\hline $2009-10$ & 1474 & $1175(20.28)$ & $1189(19.33)$ & $1177(20.14)$ & $1243(15.67)$ \\
\hline $2010-11$ & 1539 & $1444(6.43)$ & $1468(4.61)$ & $1463(4.93)$ & $1489(3.24)$ \\
\hline
\end{tabular}

Figures in ( ) are percent deviation from observed yield.

Chickpea is a Rabi (winter) crop. The effect of rainfall $\left(\mathrm{X}_{6}\right)$ on chickpea yield for different weeks, with their corresponding meteorological week (MSW) revealed that there was no significant effect of past rainfall on the yield of chickpea crop. The results of four models fitted under this approach of the Jamnagar district revealed that the variation explained by these models, ranged very high. The simulated forecasts and observed yields differed highly in most of the cases.

A brief review of studies, which have direct or indirect bearing in commensuration with the objectives of the present study.

Snedecor and cocheren (1967) ${ }^{[5]}$ used this model to study joint effect of temperature and rainfall on crop yield.

Shrivastava et al. (2002) [6] studied on the model of CHICKPGRO for the evaluation of the importance of projected climate change on yield of popular chickpea cultivar on central and north-west India.

Berger et al. (2005) ${ }^{[7]}$ revealed that Low temperatures can cause flower and pod abortion. Under field conditions, chickpea delays pod set at mean temperatures below $16^{\circ} \mathrm{C}$, and ceases podding below $12^{\circ} \mathrm{C}$.

Dubey et al. (2011) ${ }^{[8]}$ studied Impact of climate change on pulse productivity and results indicated that there was greater impact of increase in average maximum temperature on yield reduction as compared to increase in minimum temperature and the temperature difference.

Singh and Kumar (2012) ${ }^{[9]}$ concluded that Low temperature is favourable for vegetative phase and high temperature is favourable for reproductive phase of chickpea. The yield per hectare was higher during 2005-06 in comparison to 2006-07 due to favourable weather conditions in 2005-06.

Daka et al. (2019) ${ }^{[10]}$ used standard week wise approach for preharvest forecasting of mustard yield on the basis of weather variable in Banaskantha district of Gujarat.
Sabhaya et al. (2019) [11] studied the effect of weather parameters on castor yield of Banaskantha district in Gujarat and revealed that effect of rainfall was significant on castor crop.

\section{Conclusion}

The perusal of the results of Jamnagar district indicated that the approaches under study, 14 weeks period model could be suggested as a preharvest forecast model. The variation explained by this model was very high $(>86 \%)$ and simulated forecast error was less than $7 \%$. The fitted model indicated that the effect of time trend $(\mathrm{T}), 11^{\text {th }}$ week of maximum temperature, $1^{\text {st }} \& 4^{\text {th }}$ week of morning relative humidity, afternoon relative humidity of $1^{\text {st }} \& 2^{\text {nd }}$ week and $8^{\text {th }}$ week of sunshine hours were significantly and positively affected but in case of $5^{\text {th }}$ week of maximum temperature, $2^{\text {nd }}, 10^{\text {th }}$ and $12^{\text {th }}$ week of sunshine hours were negatively influenced on yield of chickpea. The weeks correspond to vegetative, flowering and maturity stages of the chickpea crop. This model could be utilized for pre-harvest forecast 2 weeks before expected harvesting of chickpea crop.

The recommended model for Jamnagar district is, $\mathrm{Y}=$ $4012.87+20.93 * * \mathrm{~T}+37.08 * * \mathrm{X}_{106}+88.12 * * \mathrm{X}_{111}-$ $40.14 * * \mathrm{X}_{112}+48.97 * * \mathrm{X}_{114}-55.28 * * \mathrm{X}_{201}-26.94 * * \mathrm{X}_{204}-$ $74.93 * * \mathrm{X}_{208}-1.09 * \mathrm{X}_{311}-0.89 * \mathrm{X}_{409}\left(\mathrm{R}^{2}=86.17 \%\right)$

\section{References}

1. Dixit GP. Project Co- ordinations Report 2014-15, Annual group meet Aug. $31^{\text {st }}$ to Sept. $3^{\text {rd }}$. AICRP on chickpea, PAU, Ludhiyana, 2015.

2. Agrawal R, Jain RC, Mehta HC. Yield forecast based on weather variables and agricultural input on agroclimatic 
zone basis. Indian Journal of Agricultural Sciences. 2010; 71(7)487-90.

3. Fisher RA. The influence of rainfall on the yield of wheat at Rothamsted Roy. Soc. (London) phil. Transser B. 1924; 213:89-142.

4. Draper NR, Smith H. Applied Regression Analysis, Johan Wiley and Sons, New York, 1966.

5. Snedecore GW, Cochran WG. Statistical Methods: Oxford and IBH Publishing Co. New Delhi. (6th Edi.), 1967.

6. Srivastava AK, Gupta BRD, Panda BC. Impact of climate change on chickpea yield in central and northwest India, Dept. of Geophysics, BHU, Varanasi, 2002, 05.

7. Berger JD, Buck RP, Henzell JM, Turner NC. Evolution in the genus Cicer - vernalization response and low temperature pod set in chickpea (C. arietinum L.) and its annual wild relatives. Australian Journal of Agricultural Research. 2005; 56:1191-1200.

8. Dubey SK, Sah U, Singh SK. Impact of climate change on pulse productivity and adaptation strategies as practiced by the pulse growers of Bundelkhand region of Uttar Pradesh. Journal of Food Legumes. 2011; 24(3):230-234.

9. Singh S, Kumar S. Crop weather relationship and its impact on growth and yield of chickpea (Cicer arietinum L.) of Uttarakhand, Department of Agrometeorology, G. B. Pant University of Agriculture and Technology Pantnagar, Uttarakhand, India. U. S. Nagar - 263145, 2012.

10. Daka SR, Chaudhary GK, Marviya PB. Preharvest forecasting of mustard yield on the basis of weather variables in Banaskantha district of Gujarat. International Journal of Agriculture Sciences. 2019; 11(8):8325-8328.

11. Sabhaya AG, Patel DV, Marviya PB. Estimation of the effect of weather parameters on castor yield of Banaskantha district in Gujarat. International Journal of Chemical Studies. 2019; 7(3):320-322. 